\title{
Critical approach to landscape-ecological mainstream topics
}

\author{
László MIKLÓS, ${ }^{1}$ Anna ŠPINEROVÁ, ${ }^{2}$ \\ Monika OFFERTÁLEROVÁ ${ }^{2}$ \\ ${ }^{1}$ Institute of Landscape Ecology of Slovak Academy of Sciences, \\ Bratislava, Slovakia, e-mail: miklos@tuzvo.sk \\ ${ }^{2}$ Technical University in Zvolen, Zvolen, Slovakia, \\ e-mail: spinerova@tuzvo.sk,monika.off@centrum.sk
}

Manuscript received April 22, 2019; revised May 29, 2019; Accepted June 02, 2019

\begin{abstract}
Nowadays, changes in environment have become characteristic of notorious mainstream political topics, with a corresponding moral, political, and financial support. The presented article deals with the landscape-ecological scientific aspects of climatic changes and of ecosystem services. The research of both phenomena is based on the complex investigation of the geosystem and, as a second step, on the scientificallybased interpretation of the obtained results. The problem resides in the question concerning the capability of scientific institutions and teams to deal with these topics with scientific profoundness, taking into account intensive public pressure and high expectations.
\end{abstract}

Keywords: science, governance, geosystems, climatic changes, ecosystem services

\section{Introduction}

The recent practical requirements towards environmental and landscape sciences drive scientists to define the object of interest - the landscape - as well as to establish its structure and functions in conformity with the forms acceptable by the policy, decision-making, planning, and projecting practice. Utmost consideration should be devoted to the interpretation of objective properties of the material reality of this object towards their application to current topics, guarding the scientific aspects of this application in any trendy challenges.

During the development of landscape sciences, several definitions of landscape were formulated. Nowadays, we can differentiate between two groups 
of considerations on the term landscape. The first group is represented by geographers and landscape ecologists and can be characterized as a geosystembased approach. The second one is popular among highly different groups of landscapers but also of social scientists, architects, and others who perceive the landscape as a cultural-historical phenomenon, a value of the environment. Such a differentiation is nothing new; several authors pointed out that the landscape can be understood in two ways: as a hard material entity and as a perception of the reality [27]; even as a genre de vive [35].

The definition of the landscape as a geosystem was promoted by scientific centres in Central Europe [28], where the main trend was presented by German landscape ecologists and geographers and by the Soviet landscape sciences school: the "landshaftovedenyje" [32]. Another group of scientists, mostly from Western Europe and North America, developed another significant landscape ecological school, based on the research of the spatial pattern of the land cover $[7,34]$. Of course, those schools were never separated and never expressed any opposition. The third considerable stream - at the same time, the newest one - of the friends and lovers of the landscape prefers the understanding of the landscape as a picture, a "scape" of the land, its cultural heritage, beauty, and values on the basis of perception [15].

This diversity of approaches also shows somehow a kind of an "identity crisis" of the landscape ecology at the turn of the millennia [36] and a considerable shift of the popularity of the understanding of the landscape concept from a material approach towards its understanding as picture, aspect, and values on the basis of perception.

Considering the legacy of all above mentioned approaches to the landscape, the basic question concerning the topic of this paper reads as follows: which approach could serve as a real scientific basis for two selected mainstream topics - climatic changes and ecosystem services? It is to be underlined that both topics, without any doubt, are of high complexity level.

Of course, we prefer the material - geosystem - approach.

\section{Materials and methods}

The article has a theoretical-methodical character. The method of the work is a critical comparison of theoretical studies on geosystems and ecosystems with a recent series of works dealing with mainstream topics [4], [5], [30]. The methodical procedure is based on the knowledge of a vast literature in this field as well as on own methodical and practical experiences in this field [17], [22]. The absolute theoretical-methodical basis of the work is the definition of the main aspects of the landscape as a geosystem concerning the climatic changes and ecosystem services as follows: 
The geosystem-based definition of the landscape is anchored on the general system theory [1], universally explained with very simple words as the set of the components of the geosphere and their mutual relations (e.g. [19], [28], [29] and also Act No. 50/1976 Zb. on territorial planning and building code as amended by Act of NC SR No. 237/2000 Z.z.). This theory ranks among the elements of the geosystem, the geological substratum, the soils, the georelief, the waters, the atmosphere, the land cover, and the man-made objects. These elements are in permanent interrelation and interaction as an integrated system, never isolated. In spite of this obvious fact, the elements of the same material object are subjects to particular sciences and also to particular sectoral managements. Of course, we insist on integrated research, management, planning, and assessment, including the concept of the ecosystem services [9].

The integrated approach is actually not a novelty. Chapter 10 of Agenda 21 from Rio Summit 1992 named "Integrated approach to the management of land resources" stated that the only space we had must be accepted by each sector. On the other hand, it is to be mentioned that not too much has happened since the Rio Summit. In reality, the above mentioned theory - the landscape as integrated entity and the need for integrated management - is generally accepted, but the analytical management of elements and the sectoral approach still prevail.

The decisive aspect of the geosystem approach for the evaluation of climatic changes, ecosystem services, and other topics is the definition of the different content and role of the primary, secondary, and tertiary landscape structure for this evaluation. Landscape is also considered as a complex natural resource which has a potential to fulfil different functions and meet different needs of the humans exactly because of its complex character - never as isolated elements of this system [10].

Considering the physical character and the role of the elements for the land use, three substructures of the landscape can be defined for the landscape management and planning [21], [22]:

- Primary landscape structure as a set of material elements of the landscape and their relations, basically the abiotic elements as the geological base and subsoils, soils, waters, georelief, and air.

- Secondary landscape structure is created by 3 groups of elements, the human-influenced, reshaped, and created material landscape elements that currently cover the Earth's surface.

- The tertiary (socioeconomic) landscape structure consists of a considerable number of socioeconomic factors/phenomena, which have very specified intangible and non-material properties such as the protection and other functional zones of nature and natural resources protection, hygienic and safety zones of industrial and infrastructure 
objects, declared zones of specific environmental measures, administrative boundaries, etc.

All these structures have decisive influence on all functions and utility values of the landscape, including the climatic changes, the realization of ecosystem services, and other topics, but in different ways.

From the point of view of environmental care, including the adaptation to climatic changes and the utilization of ecosystem services, the most important are the primary and secondary/current landscape structures because their disruption causes all the ecological problems.

\section{Results and discussions}

\subsection{The geosystem approach to the evaluation of climatic changes}

Slovakia produces less than $1 \%$ of EU's total GHG emissions but suffers the same amount of the impacts of the climatic changes as the big emitters. Therefore, it might be obvious that the adaptation policies should be more emphasized than the struggle against emissions. How to approach this problem?

In our conditions, the crucial factor of climate changes is the system of water circulation. In this respect, the geosystem as a whole and its elements (see above) plays the role of "vessel" for the water. This vessel is the river basins for surface water, and the geological substratum creates the aquafer for underground water.

This vessel decides where and how much water is present in or absent from the landscape.

In respect to climatic changes, the most dangerous factor of climatic changes in Slovakian natural conditions is the frequent sudden intensive rains and the subsequent quick and heavy run-off. The run-off then activates the whole chain of disastrous consequences such as:

- physical disasters as: flash floods on small rivers $\rightarrow$ soil erosion $\rightarrow$ accumulation $\rightarrow$ silting the reservoirs $\rightarrow$ less water capacity of the watershed and other damages to the human environment;

- ecological consequences as: unbalanced water system $\rightarrow$ overwhelming irrigation

or the opposite: draught $\rightarrow$ unfavourable changes of ecosystems.

Thus, the basic questions should be formulated as follows:

a) What causes the initial problem? Is it the rain?

Of course, the amount of run-off is done by rain. But the problems mentioned above are strongly conditioned by the "vessel", by the natural properties of all elements of the geosystem. These are the texture and 
structure of the geological substratum, the grain size of the soils, the topographic position, the slope, the vertical and horizontal curvature of the georelief, the shape of the watershed, the vegetation, the land cover, landuse, and anthropic objects - virtually the whole geosystem.

b) The other side of the question is: Are researches oriented towards this complex direction? Or, with other words: how many projects are oriented towards research on the whole geosystem and how many are oriented towards single components of the landscape, e.g. to atmospheric issues, rain, surface waters, subsurface waters, floods, draught, erosion, accumulation, etc.? Unfortunately, the last mentioned case is more common. And what is the situation with support provided by different granting systems? E.g. there are numerous projects with very different approaches concerning the waterlogging of agricultural territories as well as other projects targeting drought; or even both, waterlogging and drought may happen in the same territory, on the same fields, within the same geosystem, both problems being conditioned by exactly the same elements of the geosystem.

c) What is the routine management of these problems - an integrated approach or a sectoral one? Unfortunately, in spite of the positive development in legislation and methods, practice shows that sectoral approach still prevails.

A very specific symptomatic example is the management of the rivers and floods. Nobody doubts that floods and their management is an integrated issue par excellence. Nevertheless, the rivers and floods are assigned to the competence of water management authorities and companies. But these authorities dispose over the waters alone and neither over the territory around them nor the river basins nor the "vessel"! The territories of basins are in the ownership of most diverse entities - they mostly belong to forest and agricultural land owners; so, water managers are many times powerless in enforcing the measures that would lead to actual results.

We could mention numerous similar examples of problems concerning river basin management, water reservoir management, water pollution, and lake and wetland silting.

\subsection{The geosystem approach to the evaluation of the ecosystem services} (hereinafter as ESS)

This problem area is very different from the previous ones. The common feature of both is that the ESS concept is a complex problem just as climatic changes, and it would also need an integrated approach to research as well as to management. The basic problem is also similar, namely that the integrated approach is lacking. 
Let us clarify scientifically the content of two basic terms related to this mainstream topic:

- what is the object of the studies on "ecosystem" services?

- what are the "services" of ecosystems?

\subsubsection{Is the object of the ESS really the "ecosystem"?}

There cannot be any objection against the fact that the spatial-materialfunctional bearer of the ecosystem services is the landscape as a geosystem. What is then the relation between geosystems and the ecosystem with respect to the ESS?

Since its introduction by Tansley [33], the definition of the ecosystem has been unaltered: the ecosystem is the system of the "house" and its "inhabitants". Its material components are the abiotic surroundings (physiotop) and the biocenosis. Looking at the definition of the geosystems (see above), the elements of both the ecosystems and geosystems are the same. The difference is only the approach towards their investigation. The ecosystem approach centralizes one element - the biota - and analyses the relation of the biota to other elements, whereas the geosystem approach - theoretically - considers all elements as having equal ranks, without centralizing any one of them [29], [30].

So, the first crucial fact to be underlined is that both systems include all abiotic and biotic elements.

Another important aspect of the ecosystem concept is that it is an open system of the circulation of materials, energy, and information. This open system means also that the ecosystem does not have any borders within the landscape space since this circulation is present everywhere up to the limits of the geosphere.

So, the second crucial aspect concerns exactly the limits of the ecosystems. The ecosystem is an open system without limits, but the definition of the ESS should practically relate to concrete demarcated spatial segments of the landscape.

Respecting the above mentioned definition, when analysing the concrete content of numerous present studies on ESS, a few basic problems are to be highlighted:

a) In the majority of the present studies - including the basic publications [3] as well as the results of a broadly scoped international project on ESS, which included 27 case studies [4], [5], [30] -, the objects of the ESS are not really the ecosystems! In most cases, these are the highly simplified elements of land cover; in better cases, the simplified types of vegetation formations [2]. All these are only the elements of the secondary landscape structure. 
b) Of course, each element of land cover is at the same time also an ecosystem; nevertheless, the mentioned works evaluate only the physiognomic or the simple biotic characteristics of the selected spatial elements. But the decisive component of the ecosystems for the "production" of the ESS - the most stable structure of the ecosystem - is the abiocomplex (primary landscape structure), creating the permanent condition for all ESS, including the conditions for the renewal of the biota and thus the ESS that these studies have many times completely ignored [9].

So, from a scientific point of view - considering the goals of the ESS concept -, the most correct setting as for the object of the ESS would be the ecotop [10], [28], [29], which is defined as the physiotop + biocenosis. Ecotops respond to both major requirement towards the object of the ESS - they have a complex content and exact borders. Landscape-ecological complexes are also suitable operational units for the ESS, being spatial projections of the geosystem types [19], [22].

Nothing new! The definitions of the basic terms as ecosystem and geosystem have not changed for decades; they are still valid. However, the important thing is to recognize them and apply them in the right way in new mainstream topics as well [25].

3.2.2 What are the "services" of ecosystems? When do the properties of the ecosystems become "services"?

The ESS are divided in most of the cases according to the commonly accepted subdivision of CICES - Common International Classification of Ecosystem Services [12], [24]. According to the theoretical imaginings, the conception of ESS should be achieved as the final result of the economic evaluation of the services [3], [24]. The final practical goal is to define the complex economic value of the ecosystem as an argument by the decisionmaking process [8].

If we look at the real material-energetic matter of the ecosystems, this subdivision shows several discrepancies. Also, the real studies on the ESS display the same problems [4], [5], [16], [31], [32]. According to the material-energetic properties of ecosystems and to the functions of ecosystems, the results of the evaluations in the studies on ESS - which were entitled as ecosystem "services" - can be ranked at least into 4 groups:

a) "Products" of natural functions of ecosystems. They depend on the circulation of material, energy, and information through the geosystem as a whole. These are in constant operation - humans and other components of the ecosystems "consume" them without any action of their own [6][18]. 
According to CICES, they are marked as regulatory and supporting ESS, e.g. production of oxygen, absorption of $\mathrm{CO} 2$, regulation of run-off, geosystems, hygienic properties of ecosystems, non-productive function of the forests, support of ecological stability, bearing capacity of the landscape, or biodiversity [18], [13], [14].

b) Potentials of the ecosystems as utility values of ecosystems for humans. In CICES, these are marked as productive ESS. They depend crucially on abiotic conditions - geological substratum, georelief, soils, waters, and climate [10] based on the bonity of the soils, relief, waters, and climate. The concrete delivery of production is secondary; it depends on how the primary landscape structure is utilized, what the current land cover/land is, and how the current ecosystem as a whole functions, e.g. bioproductive potential for crops, melliferous potential, pharmaceutical potential, or air-cleaning potential [18]. It means that the same abiotic conditions can "produce" have potential - for very different productions. Nevertheless, potentials should be considered just as preconditions for whatever utilization, not service.

c) Suitability of landscape-ecological complexes for utilization by humans. This is based on both previous concepts: natural functions and the utility potentials of ecosystems. The utility values of the ecosystems can be considered for technological-localizing criteria of suitability, mostly based on abiotic properties (primary landscape structure), whereas the natural function of ecosystems for selective criteria of suitability. E.g. a certain soil type may present high potential for the production of both food crops and timber, but its final suitability for such production is defined selectively, according to land cover or biota (secondary landscape structure). In cases when the same productive soil type is in forests, meadows, or fields, its final suitability depends also on evaluation if the non-productive function of the whole ecosystem is more or less valuable than the production of biomass [24].

d) Offered and realized benefits of ecosystems for humans. These benefits become reality when humans start to utilize them. They can issue from all the properties, functions, and potentials of ecosystems as an "offer" of the ecosystems. They become "services" in cases when humans express the "demands" towards these benefits. These types of the ESS are ranked in CICES among cultural-societal and supporting ESS, e.g. offer of landscape properties for recreation, science, education, and intellectual services. The realization of these services also needs - besides the ecological/ environmental values - the appreciation of the realization criteria based on the tertiary landscape structure such as the legal provisions on nature conservation areas and protected monument zones [22]. The character of the 
cultural-societal services of ecosystems displays also the so-called importance of ecosystem for human needs [18], [19].

Another type of these services are used natural resources such as products of the material elements of geosystems for humans, e.g. water supply, mineral resources - in CICES, these are ranked among productive ESS. Nevertheless, until these resources are not utilized, they remain just potentials. Another issue is their protection by legal provisions by declaration of protective areas and zones. These zones are considered for realization criteria (based on the tertiary landscape structure).

We might conclude that in practical case studies on the ESS there are several discrepancies and scientific problems in defining the main concepts of the ESS: the "ecosystem" and the "services".

\section{Conclusions}

As it has become obvious, the central question is quite complex. Therefore, it is inevitable to define the character and content of the assessed ESS for each concrete work on the basis of deep knowledge of the geosystem, its elements, and the various properties of primary, secondary, and tertiary landscape structure. According to our experiences based on ESS assessment in concrete territories, we consider as most correct the approach of evaluation of the suitability of landscape ecological complexes for human use since this procedure includes the evaluation of all three landscape structures according to all technological (abiotic), selective (biological-ecological), and realization (socioeconomic) criteria [23].

The diversity of understanding the object of evaluation of the ESS as well as the diversity of the definition of ESS also presume a big diversity of the methods of the evaluation of ESS. Actually, there is no generally accepted method of the ESS evaluation but very different methods of the assessment of the utility functions and values of the nature and landscape - older or newer -, which results are renamed as ESS [20], [26], [16], [4], [5], [30]. However, the potential of older methods is not yet exhausted - they are well elaborated and are many times much more accurate than present-day methods that use just the estimates of the obvious functions of landscapes. Anyway, the presented article does not deal with these problems.

As a general conclusion, we underline the following basic aspects:

The source of all above mentioned - seemingly different - consequences of climatic changes from floods to drought as well as the provision of ecosystem services is the circulation of material, energy, and information through the geosystem as a whole. This conditions the behaviour of the system and the consequences of the interconnections and interrelations of the elements of the geosystem. Therefore, the scientifically based solution of these problems needs: 
- a complex, scientifically based geosystem approach to basic research;

- scientifically based procedures for the application of the results of basic science;

- scientifically based interpretations of the purpose-oriented characteristics also in cases of much pressure on the part of the public regarding the results in mainstream topics;

- integrated - not sectoral - management of the landscape as a whole in all mainstream problems.

All above mentioned preconditions have sufficient theoretical-methodical basis, legal support, good planning and projecting tools. The only insufficiency concerns their integration.

\section{Acknowledgements}

This article is the result of the research funded by the operational programme Research and Development, project: NFP313010X649 - "Evaluation of the changes of the landscape and their impact on the environment", which was cofinanced by the European Regional Development Fund.

\section{References}

[1] Bertalanffy, L. von, (1968), General system theory. Foundations, development and applications. New York: George Brazileer. Penguin Books.

[2] Burkhard, B., Kroll, F., Müller, F., Windhorst, W. (2009), Landscapes' capacities to provide ecosystem services - A concept for land-cover-based assessments. Landscape Online 15, 1-22.

[3] Costanza, R. et al. (1997), The value of the world's ecosystem services and natural capital. Nature 387, 253-260.

[4] Dick, J. et al. (2014), Ecosystem services: A rapid assessment method tested at 35 sites of the LTER-Europe Network. Ekológia (Bratislava) 33(3), 217-231.

[5] Dick, J. et al. (2018), Stakeholders' perspectives on the operationalisation of the ecosystem service concept: Results from 27 case studies. Ecosystem Services 29, 552-565.

[6] Eliáš, P. (2010), Od funkcií vegetácie k ekosystémovým službám. Životné prostredie 44(2), 59-64.

[7] Forman, R. T. T., Godron, M. (1981), Patches and structural components for landscape ecology. BioScience 31, 733-740.

[8] Gomez-Baggethum, E., Barton, D. (2013), Classifying and valuing ecosystem services for urban plannig. Ecological Economics 86, 235-245.

[9] Grunewald, K., Bastian, O. (eds.) (2015), Ecosystem services - Concepts, methods and case studies. Berlin-Heidelberg: Springer-Verlag.

[10] Haase, G. (1978), Zur Ableitung und Kennzeichnung von Naturraumpotentialen. Petermanns Geogr. Mitt. 122(2), 113-125.

[11] Haase, G. (1980), Izučenie topičeskich i choričeskich struktur, ich dinamiki i razvitija v landšaftnych sistemach. Structura, dinamika i razvitije landšaftov. Moskva: Institut geografii AN SSSR. 57-81. 
[12] Haines-Young, R., Potschin, M. (2013), Common International Classification of Ecosystem Services (CICES), consultation on version 4. August-December 2012, EEA Framework Contract No EEA/IEA/09/003.

[13] Halada, L., Topercer, J., Kartusek, V., Mederly, P. (1995), Systém ekologickej kvality krajiny - d’alší prístup k manažmentu krajiny. Životné prostredie 29(5), 271-273.

[14] Hrnčiarová, T. (1998), Ekologická a kultúrna významnost’ krajiny vyplývajúca z legislatívnych predpisov. In: Izakovičová, Z., Kozová, M., Pauditšová, E. (eds.), Implementácia trvalo udržatel'ného rozvoja. Bratislava: ÚKE SAV. 99-103.

[15] Hynek, A. (2010), Krajina: objekt, nebo konstrukt? In: Herber, V. (ed.), Fyzická geografie a kulturní krajina. Fyzickogeografický sborník 8, 138-142. Brno: Masarykova Univerzita.

[16] Izakovičová, Z. et al. (2012-2017), Funkčnost' prírodných kapitálov a ekologických služieb: od konceptu k reálnej aplikácii (OpenNESS), Projekt EK 308428, Ústav krajinnej ekológie SAV Bratislava, SYKE Helsinki.

[17] Izakovičová, Z., Świader, M. (2017), Building ecological networks in Slovakia and Poland. Ekológia (Bratislava) 36(4), 303-322.

[18] Jurko, A. (1990), Ekologické a socioekonomické hodnotenie vegetácie. Príroda, Bratislava.

[19] Krcho, J. (1968), Prírodná čast' geosféry ako kybernetický systém a jeho vyjadrenia v mape. Geografický časopis (Bratislava) 20(2), 115-130.

[20] Lamarque, P., Que-Tier, F., Lavorel, S. (2011), The diversity of the ecosystem services concept and its implications for their assessment and management. Comptes Rendus Biologies 334, 441-449.

[21] Miklós, L., Izakovičová, Z. (1997), Krajina ako geosystem. Bratislava: VEDA.

[22] Miklós, L., Kočická, E., Izakovičová, Z., Kočický, D., Špinerová, A., Diviaková, A., Miklósová, V. (2019), Landscape as a geosystem. Springer.

[23] Miklós, L., Špinerová, A. (2019), Landscape-ecological planning LANDEP. Springer.

[24] Millennium Ecosystem Assessment. (2005), Ecosystems and human well-being: Synthesis. Washington, DC: Island Press-World Resources Institute.

[25] Mizgajski, A., Markuszewska, I. (eds.). (2010), Implementation of landscape ecological knowledge in practice. The problems of landscape ecology, vol. XXVIII. Poznań: Polish Association for Landscape Ecology, Wydawnictvo Naukowe, Adam Miczkiewicz University.

[26] Nahlik, A. M., Kentula, M. E., Fennessy, M. S., Landers, D. H. (2012), Where is the consensus? A proposed foundation for moving ecosystem service concepts into practice. Ecological Economics 77, 27-35.

[27] Naveh, Z., Liebermannn, A. (1994), Landscape ecology - Theory and application. Second edition. New York-Berlin-Heidelberg: Springer-Verlag.

[28] Neef, E., Richter, H., Barsch, H., Haase, G. (1973), Beitrage zur Klärung der Terminologie in der Landschaftsforschung. Beitrag'd. Institut d. Geographie and Geoökologie d. Akad. d Wiss. d. DDR. Beilage zu Práce a materiály z biológie krajiny 20.

[29] Preobrazhensky, V. S. (1983), A system orientation of landscape research in geography and its present-day realization. In: Drdoš, J. (eds.), Landscape synthesis, geoecological foundations of the complex landscape management. Bratislava: VEDA. 31-36.

[30] Saarikoski, H. et al. (2018), Institutional challenges in putting ecosystem service knowledge in practice. Ecosystem Services 29, 579-598.

[31] Šedivá, A., Izakovičová, Z. (2015), Assessment of representative landscape types of Skalica district. Ekológia (Bratislava) 34(4), 329-338.

[32] Sochava, V. B. (1977), Vvedenje v učenije o geosystemach [in Russian]. Novosibirsk: Nauka.

[33] Tansley, A. G. (1935), The use and abuse of vegetational concepts and terms. Ecology 16, 284-307. 
[34] Turner, M. (1990), Spatial and temporal analysis of the landscape patterns. Landscape Ecology 4(1), 21-30.

[35] Vidal de la Blache, P. (1922), Principes de géographie humaine. Source: Encyclopaedia Britannica - http://www.britannica.com/EBchecked/topic/627886/Paul-Vidal-de-la-Blache.

[36] Wu, J. (2013), Key concepts and research topics in landscape ecology revisited: 30 years after the Allerton Park workshop. Landscape Ecology 28, 1-11. 